\title{
Students' self-regulation and motivation in learning science
}

\author{
Tanti $^{1}$, Maison ${ }^{2}$, Boby Syefrinando ${ }^{3}$, Mahbub Daryanto ${ }^{4}$, Hayyu Salma ${ }^{5}$ \\ ${ }^{1,5}$ Faculty of Science and Technology, Universitas Islam Negeri Sultan Thaha Saifudin Jambi, Indonesia \\ ${ }^{2}$ Faculty of Teaching and Education, Universitas Jambi, Indonesia \\ ${ }^{3,4}$ Faculty of Tarbiyah and Teacher Training, Universitas Islam Negeri Sultan Thaha Saifudin Jambi, Indonesia
}

\begin{tabular}{|c|c|}
\hline Article Info & ABSTRACT \\
\hline Article history: & \multirow{9}{*}{$\begin{array}{l}\text { The student's self-regulation and motivation are essential for students to } \\
\text { study. Especially with } 21 \text { st-century learning students are required to be more } \\
\text { active in learning than teachers. This Mixed Methods research aimed to } \\
\text { determine the influence between the students' self-regulation with the } \\
\text { motivation of students learning. The sample size was } 534 \text { students from } \\
\text { Madrasah Tsanawiyah in Jambi city, Indonesia determined by total sampling } \\
\text { technique. Data were then analyzed with the SPSS } 21 \text { application to find } \\
\text { descriptive statistics as well as inferential statistics using simple regression } \\
\text { and for comparison using the independent sample T-Test. The results of this } \\
\text { research are dominant in both self-regulation and student motivation in } \\
\text { learning, which is strengthened by the relationship and influence between } \\
\text { self-regulation and the motivation of students in learning. It is seen from the } \\
\text { value of sig = } 0.019 \text { and has a contribution of } 70.3 \% \text {. According to the } \\
\text { results, it is recommended that students need to be given the opportunity to } \\
\text { conduct learning directly and teachers must perform innovative learning. }\end{array}$} \\
\hline Received Apr 8, 2020 & \\
\hline Revised Sep 19, 2020 & \\
\hline Accepted Oct 13, 2020 & \\
\hline Keywords: & \\
\hline Motivation & \\
\hline Science & \\
\hline Self-regulation & \\
\hline Students & \\
\hline
\end{tabular}

This is an open access article under the CC BY-SA license.

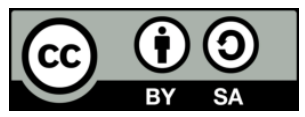

Corresponding Author:

Tanti,

Faculty of Science and Technology,

Universitas Islam Negeri Sultan Thaha Saifudin Jambi,

Jln. Jambi - Muara. Bulian, KM.18, Jambi, 36361 Indonesia.

Email: tanti@uinjambi.ac.id

\section{INTRODUCTION}

Education is one of the most important things in human life. Because through human education can develop their horizons, so they will be able to deal with every problem and change through an open attitude with a creative approach without losing their identity [1-4]. The Government has made various efforts and policies in order to improve the quality of education, including: Perfecting the curriculum, freeing upschool fees for elementary school and junior high students, doing activities that can improve their thinking skills, Complete facilities and infrastructures such as: science laboratories, computer laboratories, libraries and many more facilities and infrastructures that support student learning, updating learning models and methods, and holding certification Teachers, upgrades and seminars [5, 6].

Science lessons According to the 2013 curriculum, emphasizing that students are encouraged to learn through active involvement with the skills, concepts, and principles in each science lesson [7]. Learning will be increasingly difficult to adjust to the level. In elementary school, science lessons are only limited to the introduction of nature and the environment, while the junior high school science lessons are more focused. The scope of science in junior high school focuses on observing natural phenomena and its application in daily life, in addition to issues concerning natural phenomena related to productive competence and expansion of abstract concepts. Learning about abstract concepts gives students difficulty in understanding science lessons. Students must therefore have an attitude toward the subject of science. 
Attitudes are an individual's tendency to act, think, understand, and feel in the face of an object, idea, situation, or value [8,9]. In addition, Kurniawan [10] said that attitudes towards science show that students will be interested or have feelings for science. This statement explains whether the student likes or does not like science. In order to know the attitude of students to the natural sciences, the attitude measured according to Fraser's [11], TOSRA (Test of Science-attitude related). The attitudes that students possess have an influence on self-regulation and student motivation in the teaching.

Several studies in science education proved that motivation and self-regulatory ability are two important factors that determine students ' success in the learning process. Motivation plays an important role in providing energy, directing, and maintaining positive student behavior to always be actively involved in the learning process, and to influence the development of student learning [12-14]. Students with high motivation for learning tend to have a positive attitude in learning, such as focusing on following the learning process, which is actively involved in class activities, often filing Teachers' questions, and always have time to learn [15]. Furthermore, motivation is the main need that students need to have their own regulatory skills. Self-regulatory capability consists of two main components; the ability to use, effective and efficient learning strategies, and the ability to motivate ourselves to always actively participate in the learning process [16]. Students are said to have the ability to Self-regulation if they can use a variety of learning strategies, and be able to decide when, why, and how to use this strategy in the right context.

Various research literature in the field of science education shows that the learning environment is a major factor that plays an important role in encouraging students to have high motivation and good selfregulatory skills [17]. So far, there has been a lot of research proving that constructivism-based learning environment focuses on students oriented (student-centered learning) to increase student motivation in learning science [18, 19]. A study conducted by Maison [20], shows that the task of orientation and investigation is a psychosocial factor in the learning environment that has the most positive and significant effect on the learning of motivation and self-regulation. However, there are limited studies in Indonesia to explore the psychosocial factors of a learning environment that have a significant impact on student motivation, as well as analyzing the dimension of motivation that is positively correlated with the formation of self-regulation in learning integrated sciences. Therefore, to address the research gaps, the main goal of this study is to explore the main factors of the learning environment that have a significant impact on the motivation and self-regulation strategy, and to evaluate the main components of motivational learning that has a significant impact on the use of Self-regulatory strategies of students by establishing structural models of relationships between learning environment, motivation, and student self-regulation strategies in learning science Integrated knowledge.

Self-regulation in good learning will help a person in fulfilling the various demands he faced. Vohns [21], mentioning the existence of self-regulation in learning will make the individual set the goal, evaluate it and make the necessary adaptation so as to support the achievement. Other research results also show that self-regulation in learning has a great role in achieving one's academic achievement [22-24]. Cheng described that someone who can do self-learning has a clear idea of how and why self-regulatory strategies in learning should be used [24]. They are active learners in the case of Metacognitive, motivation and control of actions. Further explained by Cheng [24] in the self-learning process, one needs to organize their learning objectives, create learning plans, choose their learning strategy, monitor their learning process, evaluate learning outcomes them and suppress distractions.

\section{RESEARCH METHOD}

This research employed mixed method approach. Mixed methods can refer to the use of quantitative and qualitative data in answering research questions and is part of a larger research program and designed as a complement to provide Information related to different methodological approaches [25]. The type used is sequential explanatory. Sequential Explanatory is a research that data collection initially is quantitative which is then followed by qualitative data, which means that the quantitative data is strengthened by the qualitative data to be acquired [26].

Where, quantitative data are obtained through the provision of motivation questionnaire and selfregulation, then followed by qualitative activities that are conducting interviews with students. The study used 534 students in classes VII and VIII with details of 324 female students and 210 male students of MTS Madrasah who were equivalent to junior high school in Jambi city using total sampling techniques. The total sampling technique is an example of a collection technique that uses the entirety of a population [27]. Interview only conducted to 20 students who are willing to conduct the interview. Instruments in this study are questionnaire, and interviews. Cohen, et al. [28] stated that questionnaire is a list of questions given to others who are willing to answer (the respondents) according to the user's request. 
In the process of collecting the first data, because it uses a sequential type of explanation, the data obtained first is quantitative data through motivation questionnaire and self-regulation. The self-regulatory questionnaire was adapted and had a valid declaration of 21 statements with a Cronbach alpha value of 0.73 , as well as a learning motivation for students obtained a valid statement of 22 statements with a Cronbach Alpha value of 0.76 that uses the Likert scale of 4 , namely for a positive statement strongly disagree have a score of 1 , do not agree to have a score 2 , agree to have a score 3 and strongly agree 4 . Then, do a semistructured interview to confirm the quantitative results that have been done. Then to process SPSS 21 data is used to look for descriptive statistics to see quantitative data, while for qualitative data using miles \& Huberman, i.e. data reduction, data display, and conclusion [28]. Descriptive statistics are presented in the frequency of summary, such as mean, mode, median, minimum, maximum and standard deviation [28]. In this study the descriptive statistics used are mean, Min, Max, and Category. For the categories in this study can be seen in Table 1 .

Table 1 Categorization of self-regulation and motivation

\begin{tabular}{cccc}
\hline \multirow{2}{*}{ Category } & \multicolumn{3}{c}{ Interval } \\
& Metacognitive & Elaboration & Motivation \\
\hline Very Not Good & $21.0-36.7$ & $21.0-36.7$ & $22.0-38.5$ \\
Not Good & $36.8-52.5$ & $36.8-52.5$ & $38.6-55.0$ \\
Good & $52.6-68.2$ & $52.6-68.2$ & $55.1-71.5$ \\
Very Good & $68.3-84.0$ & $68.3-84.0$ & $71.6-88.0$ \\
\hline
\end{tabular}

During data collection as can be seen in Figure 1, the first activity that must be done is to select students based on the categories provided by the researcher, then give questionnaire of self-regulation and motivation to students. The questionnaire is then processed using SPSS 21 application data to see descriptive statistics, in the form of, the mean, min, max, percentage, and category of students and find out if there is an impact and comparison between the two variables.

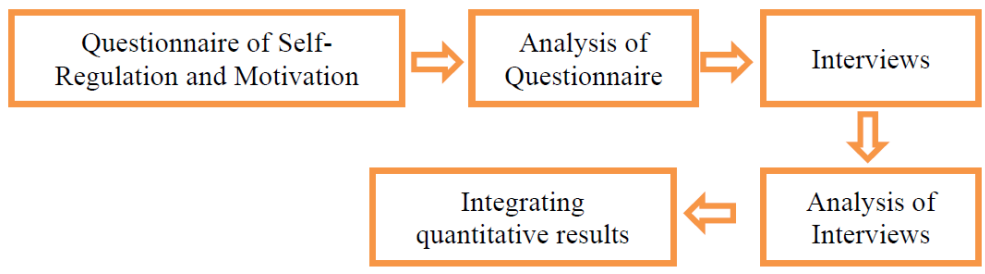

Figure 1. Data collection

All data were obtained from the motivation and self-regulation questionnaires on student values and collected and calculated and assisted with the SPSS 21 application. Descriptive statistics are given to calculate the frequency, percentage, mean, Min, and Max of a sample [26]. In this study, quantitative data were analyzed using parametric statistics of simple regression to determine whether there was an impact between student self-regulation, and student motivation; then see the difference between class VII and VIII in self-regulation and its motivation this study used SPSS 21 at significance level 0.025 . Interviews are used conducted to reinforce quantitative data outcomes, which is analyzed using Miles and Huberman [29], including reducing data, displaying data, and concluding.

\section{RESULTS AND DISCUSSION}

\subsection{Results}

\subsubsection{Metacognitive students in self-regulation}

The results of the questions given and the results obtained using the SPSS 21 can be seen in the Table 2. From Table 2, which came from 534 respondents from the Madrasah Tsanawiyah in Kota Jambi after they were obtained and the results obtained using the SPSS 21 application program, on the indicator of teacher support in the student learning environment has the dominant results Is good, with a percentage of $67.6 \%$ for 361 students from a total of 534 students, and very unwell amounting to $5.4 \%$ for 29 students of the total 534 students. From 534 students, the mean result is 57.4 , maximum value 79 , and a minimum value of 26. 
Table 2. The result of metacognitive in student self-regulation in learning science

\begin{tabular}{ccccccccc}
\hline \multicolumn{2}{c}{ Classification } & & & \multirow{2}{*}{ Mean } & \multirow{2}{*}{ Min } & \multirow{2}{*}{ Max } & \multirow{2}{*}{$\%$} \\
\hline Range & Respond & M & F & Total & & & & 5.4 \\
$31.0-36.7$ & Not very good & 19 & 10 & 29 & & & & 8.8 \\
$52.8-52.5$ & Not good & 27 & 20 & 47 & \multirow{2}{*}{57.4} & \multirow{2}{*}{26} & 79 & 67.6 \\
$68.3-88.2$ & Good & 123 & 238 & 361 & & & & 18.2 \\
Total & Very good & 41 & 56 & 97 & & & & 100 \\
\hline
\end{tabular}

\subsubsection{Elaboration in self-regulation}

The results of the questions given and the results obtained using the SPSS 21 application can be seen in the Table 3. From Table 3, which came from 534 respondents from the Madrasah Tsanawiyah in Kota Jambi after they were obtained and the results obtained using the SPSS 21 application program, on the elaboration indicator in the student self-regulation has the dominant result is good, with a percentage of $66.3 \%$ for 354 students from a total of 534 students, and very unwell amounting to $7.3 \%$ for 39 students from a total of 534 students. From 534 students, the mean result is 59.2, maximum value 80, and a minimum value of 26.

Table 3. Result of elaboration in student self-regulation in learning science

\begin{tabular}{|c|c|c|c|c|c|c|c|c|}
\hline \multicolumn{5}{|c|}{ Classification } & \multirow{2}{*}{ Mean } & \multirow{2}{*}{ Min } & \multirow{2}{*}{ Max } & \multirow{2}{*}{$\%$} \\
\hline Range & Respond & M & $\mathrm{F}$ & Total & & & & \\
\hline $21.0-36.7$ & Not very good & 20 & 19 & 39 & & & & 7.3 \\
\hline $36.8-52.5$ & Not good & 27 & 21 & 47 & 505 & 26 & 80 & 8.8 \\
\hline $52.6-68.2$ & Good & 133 & 221 & 354 & 59.5 & 26 & 80 & 66.3 \\
\hline $68.3-84.0$ & Very good & 29 & 65 & 94 & & & & 17.6 \\
\hline Total & & 210 & 324 & 534 & & & & 100 \\
\hline
\end{tabular}

\subsubsection{Motivation}

The results of the questions given and the results obtained using the SPSS 21 application can be seen in the Table 4. From Table 4, which came from 534 respondents from the Madrasah Tsanawiyah in Kota Jambi after they were obtained and the results obtained using the SPSS 21 application program, on learning motivation students have the dominant result is good, with a percentage of $59.7 \%$ for 319 students from a total of 534 students, and very unwell amounting to $5.6 \%$ for 30 students of the total 534 students. From 534 students, the mean result is 67.4, maximum value 87, and a minimum value of 27 .

Table 4. The result of student motivation to learn science

\begin{tabular}{|c|c|c|c|c|c|c|c|c|}
\hline \multicolumn{5}{|c|}{ Classification } & \multirow{2}{*}{ Mean } & \multirow{2}{*}{ Min } & \multirow{2}{*}{ Max } & \multirow{2}{*}{$\%$} \\
\hline Range & Respond & M & $\mathrm{F}$ & Total & & & & \\
\hline $22.0-38.5$ & Not very good & 18 & 12 & 30 & \multirow{5}{*}{67.4} & \multirow{5}{*}{27} & \multirow{5}{*}{87} & 5.6 \\
\hline $38.6-55.0$ & Not good & 36 & 25 & 61 & & & & 11.4 \\
\hline $55.1-71.5$ & Good & 110 & 209 & 319 & & & & 59.7 \\
\hline $71.6-88.0$ & Very good & 46 & 78 & 124 & & & & 23.3 \\
\hline Total & & 210 & 324 & 534 & & & & 100 \\
\hline
\end{tabular}

\subsubsection{Class VII and class VII differences in learning environment}

To see the differences in the learning environment of students in classes VII and VIII can be seen in the Table 5. From Table 5 it can be seen that the value obtained ( $t$ arithmetic) with the value of $t$ table. Ttable values can be found in the t table with a significance value of 0.025 (2-tailed test) with a degree of freedom (df) 534. In this study, the results for t table are 1.967903. As for the $t$ value, it can be seen in Table 5. (Column t) that is 20.153. So, it can be concluded that there are significant differences in learning environment students' in class VII and VIII.

Table 5. Independent sample t-test for self-regulation

\begin{tabular}{ccccccc}
\hline \multirow{2}{*}{$\mathrm{T}$} & \multirow{2}{*}{$\mathrm{df}$} & \multirow{2}{*}{ Mean } & \multirow{2}{*}{ Std.Deviation } & \multicolumn{2}{c}{ 95\% confidence interval } \\
& & & & & Lower & Upper \\
\hline \multirow{2}{*}{ Self-regulation } & 20.153 & 534 & 3.0906 & .14321 & 18.236 & .6120 \\
& 20.153 & 239.067 & 2.4033 & .19015 & 17.935 & .8615 \\
\hline
\end{tabular}




\subsubsection{Class VII and class VII differences in student motivation}

To see the student motivation differences in classes VII and VIII can be seen in the Table 6. From Table 6 it can be seen that the value obtained (t arithmetic) with the value of t table. T-table values can be found in the $\mathrm{t}$ table with a significance value of 0.025 (2-tailed test) with a degree of freedom (df) 534. In this study, the results for $t$ table are 1.967903. As for the $t$ value, it can be seen in Table 6. (Column $t$ ) that is 20.553. The hypothesis testing criteria is that there is a rejection value of $\mathrm{H}_{0}$ (Cramer, 2003). So, it can be concluded that there are significant differences in motivation students' in class VII and VIII.

Table 6. Independent sample t-test for motivation

\begin{tabular}{ccccccc}
\hline & \multirow{2}{*}{$\mathrm{T}$} & \multirow{2}{*}{$\mathrm{df}$} & \multirow{2}{*}{ Mean } & \multirow{2}{*}{ Std.Deviation } & \multicolumn{2}{c}{$95 \%$ confidence interval } \\
& & & & & Lower & Upper \\
\hline \multirow{2}{*}{ Motivation } & 20.553 & 534 & 3.2306 & .14321 & 18.236 & .6120 \\
& 20.553 & 241.067 & 2.3033 & .18315 & 17.935 & .8615 \\
\hline
\end{tabular}

\subsubsection{The regression}

For the results of the influence of a learning environment with students' motivation can be seen in Table 7. From Table 7, it can be seen the results of a simple regression test found that the regression equation is $\mathrm{Y}=13.561+0.229 \mathrm{X}$. For the number of contributions from self-regulation on motivation can be seen in Table 8. The result of a simple regression analysis (Table 8) suggests that the value of the coefficient of determination is $\left(\mathrm{R}^{2}\right)$ 0.703. This means that the contribution of self-regulation to the motivation of learning is $70.3 \%$, while the remaining $29.7 \%$ is influenced by other variables.

Table 7. Results of regression

\begin{tabular}{cccccc}
\hline \multirow{2}{*}{ Variable } & \multicolumn{2}{c}{ Unstandardized Coefficients } & Standardized Coefficients & $\mathrm{t}$ & sig. \\
& $\mathrm{B}$ & Std. Error & Beta & & \\
\hline 1 (Constant) & 13.561 & 3.151 & & 4.584 & .000 \\
Self-regulation & .229 & .224 & .223 & 1.328 & .019 \\
\hline
\end{tabular}

Table 8. Contribution of learning environment on motivation

\begin{tabular}{ccccc}
\hline Model & R & R square & Adjust R Square & Std. Error of the Estimate \\
\hline 1 & .823 & .703 & .712 & 2.703 \\
\hline
\end{tabular}

\subsection{Discussion}

The results of the analysis of questionnaires in Table 2, a metacognitive indicator in the SelfRegulation in the junior lesson has a good metacognitive capability of 67.6\% (361 of 534) students in science subjects. The ability is demonstrated by being able to design an answer and think of answers as desired. It can also be seen from the results of interviews that have been done.

"When you know there will be a test next week, what do you do?"

"I will prepare myself before the test"

"What kind of preparation do you mean?"

"Like learning every night about lessons to be tested, and praying"

Metacognitive is part of an individual's ability when thinking about designing or planning the action you want to take. Metacognitive is done by early childhood when given information by using questions after being given questions or assignments then the aspect that plays a lot Determining the regulation of himself is metacognitive then gives rise to the conclusion that the self-regulation in the strategy of acceptance of information and good learning is correlated with metacognitive ability [30, 31]. In Dinsmore Research comparing the underlying aspects of self-regulation, it is found that metacognitive plays an important role as a person's self-regulatory forming [32].

The results of the analysis of the questionnaire on Table 3, the elaboration indicator in the Selfregulation in the junior lesson has a good elaboration capability of $66.3 \%$ (354 of 534) students in the science subjects. The ability is demonstrated by explaining something in detail from other people, because it has good elaboration skills. It can also be seen from the results of interviews that have been done. 
"When you meet a friend, you are unable to explain a problem, what do you do?" "I'll examine the issue in more detail than my friend did, so I'd get the answer I wanted" "When your friend explained something of a problem that he encountered, what would you do?" "I will add, clarify or elaborate deeper back so that the problem can be missed"

Elaboration is the ability to explain, develop, enrich or elaborate more detailed answers or ideas given. By having this ability student can answer the problems that have been given [33-35]. Students who have this ability will also have a good value because it will help his friend in enriching ideas that other people have.

The results of the survey analysis in Table 4, is the motivation of students in learning who have a good category of 59.7\% (319 of 534) students in the junior lesson. This is demonstrated by the student's interest in learning and is characterized by more active students in class. It can also be seen from the results of interviews that have been done.

\section{"How do you think the circumstances of friends are in class?" \\ "My friend on average has more interest in learning" \\ "What is the evidence, that your friends are more interested in the learning?" \\ "My friends are more active in the classroom, such as asking questions, answering questions, and always engaging in classes"}

Learning motivation can arise due to intrinsic and extrinsic factors, one of the extrinsic factors is a conducive learning environment. Conducive means truly supporting the sustainability of the learning process. The atmosphere during the learning process can affect the efficiency of learning time with a less conducive atmosphere that will make students not focused on the learning process so that the learning time is not effective [36, 37]. In line with this, Hidi explains that conducive environment is a driving factor that provides an appeal for the learning process, otherwise the less pleasant environment will cause saturation and boredom [38-40]. Teachers and parents who always provide a good example for a child, a social companion who provides positive life lessons, a quiet learning area, and a complete lesson tool can improve students' motivation to learn.

Students' ability to regulate themselves in the learning process is an important activity in the student learning process. According to Sungur, et al. [41], Social cognitive learning theory has explained the ideal concept of learners, i.e., self-regulation-based learners. Self-regulation-based learning term is a translation of self-regulated learning foreign words. Self-regulation-based learning is a topic that is often researched and studied in recent years. Various variables affecting the regulation self-based learning variables include the Problem Based Learning model [42, 43]. Period of study, learning environment, cognitive self-regulation, learning Motivation, Acceleration class, the level of IT integration (information Technology) which includes the ability Use of IT and attitude towards IT, learning motivation and interaction of teachers and students $[44,45]$.

Based on the self-regulatory process of Zimmerman [46], there are three stages of self-regulation, namely the forward orientation stage, the performance stage, and the self-reflection stage. The forward orientation stage consists of two main processes: The task analysis and the confidence of self-motivation. Task analysis consists of goal setting and strategy planning. Self-motivation beliefs consist of self-efficacies, hope towards results, interests/intrinsic value and orientation learning objectives. The performance stage consists of two processes namely self-control and self-observation. Self-control consists of imagination, selfbriefing, centring attention, and learning strategy. Self-observation consists of two main processes: selfrecording or self-recording of personal events, and self-experimentation to get the cause of the event. The self-reflection stage consists of two main processes: self-judgement and self-reaction. The form of selfassessment is self-evaluation, which compares the results of self-observation of the pre-existing performance standards, the performance of others, or the absolute performance standards [47]. Another form of selfassessment is the causal attribution that points to beliefs about the cause of success or error [48, 49]. The form of self-reaction on self-regulation-based learning cycles consists of self-satisfaction and adaptive or defensive response. Increased self-satisfaction in the stage of self-reflection increases motivation, while decreasing self-satisfaction will undermine learning efforts. Reaction adaptation will result in self-adjustment directed at the increased effectiveness of a learning method.

Motivation is a series of businesses to provide certain conditions, so someone wants to do something. Motivation is an encouragement in one's self to try to make a better behavior change in fulfilling the need only [50]. In the learning activities, motivation is the driving force in the students that raises the learning activities, which guarantees the continuity of the learning activities and that gives direction to the learning activities, so that the objectives desired by the subject of study It is accomplished [51, 52]. That is, 
students who have strong motivation will have a lot of energy to do learning activities. Motivation will be aroused if the atmosphere of a good class, sufficient classroom, the existence of freedom to move, light and good air circulation will spur the motivation to learn students well according to ability [53]. This means that schools and classrooms need to be managed properly, and create a learning climate that supports learning. Astalini, et al; and Maison, et al. state that the lack of motivation will lead to less-than-motivated students in learning $[54,55]$.

The exploration of the relationship between students ' motivation using the Self-regulatory strategy shows that extrinsic goal orientation is the most significant motivation dimension for the use of selfregulatory strategies for students in integrated learning of science knowledge, both in cognitive strategies (organizations), and in metacognitive strategies (critical Thinking and Metacognitive) [56, 57]. On the other hand, extrinsic goal orientation is part of the goal orientation that explains why a student is actively engaged in learning and performing tasks related to extrinsic reasons, such as obtaining an award from a teacher, Peers, and parents, get good grades, or avoid punishment [58]. Therefore, there is the influence of selfregulation with the motivation of students in the study of science.

\section{CONCLUSION}

The research found that the outcome of the student self-regulation has a good category because, with the students having a good attitude will make himself comfortable in learning that will affect the motivation that belongs to the student. If students who have good self-regulation, it will encourage the extrinsic motivation of students. It is also supported by the relationship between student self regulation and student motivation and there is an influence between the two variables with a contribution of $70.3 \%$. According to the results, it is recommended that students need to be given the opportunity to conduct learning directly and teachers must perform innovative learning.

\section{REFERENCES}

[1] Astalini, et al., "Characteristics Of Students' Attitude To Physics In Muaro Jambi High School," Humanities \& Social Science Reviews (HSSR), vol. 7, no. 2, pp. 91-99, 2019.

[2] Darmaji, et al., "Mobile Learning In Higher Education For The Industrial Evolutioin 4.0: Perception and Response of Physics Practicum," International Journal of Interactive Mobile (IJIM), vol. 13, no. 9, pp. 4-20, 2019.

[3] R. S. Budiarti, et al., "High Oder Thinking Skills for Biology Education: Applied Microbiology Learning Videos Based on Jambi Local Wisdom," Universal Journal of Education Resaerch, vol. 8, no. 2, pp. 689-694, 2020.

[4] Maison, Darmaji, Astalini, D. A, Kurniawan, Sumaryanti, and R. Perdana, "Supporting Assessment in Education: E-Assessment Interest in Physics," Universal Journal of Education Research, vol. 8, no. 1, pp. 89-97, 2020.

[5] Asrial, et al., "Supporting Technologi 4.0: Ethnoconstructivist Multimedia for Elementary Schools," International Journal of Online and Biomedical Engineering (iJOE), vol. 15, no. 9, pp. 4-15, 2019.

[6] Syahrial, et al., "Increased behavior of students' attitudes to cultural values using the inquiry learning model assisted by ethnoconstructivism," Journal of Educational Science and Technology, vol. 5, no. 2, pp. 176-188, 2019.

[7] D. A. Kurniawan, et al., "Etnoscience Investigation in Pimary Schools: Impact on Science Learning," Universal Journal of Educational Research, vol. 7, no. 12, pp. 2789-2795, 2019.

[8] Astalini, Darmaji, W. Kurniawan, K. Anwar, and D. A, Kurniawan, "Effectivenes of Using E-module and EAssessment," International Journal of Interactive Mobile (IJIM), vol. 13, no. 9, pp. 21-39, 2019.

[9] Maison, Darmaji, Astalini, D. A, Kurniawan, and P. S, Indrawati, "Science Process Skills And Motivation," Humanities \& Social Science Reviews (HSSR), vol. 7, no. 5, pp. 48-56, 2019.

[10] D. A, Kurniawan, et al., "Evaluation of Junior High School Students' Attitudes Against Science in Muaro Jambi Regency (in Bahasa)," Jurnal Ilmiah Didaktika: Media Ilmiah Pendidikan dan Pengajaran, vol. 19, no. 1, pp. 124-139, 2019.

[11] B. J. Fraser and H. J. Walberg, "Psychosocial learning environment in science classrooms: A review of research," Studies in Science Education, vol. 8, no. 1, 1981.

[12] K. M, Law, S. Geng, and T. Li, "Student enrollment, motivation and learning performance in a blended learning environment: The mediating effects of social, teaching, and cognitive presence," Computers \& Education, vol. 136, no. 2, pp. 1-12, 2019.

[13] T. Tasiwan, S. E, Nugroho, and H. Hartono, "Analysis of the Level of Student Motivation in Natural Science Learning Project-Based Advance Organizer Model (in Bahasa)," Jurnal Pendidikan IPA Indonesia, vol. 3, no. 1, 2014.

[14] S. Velayutham, J. Aldridge, and E. Afari, "Students' learning environment, motivation and self-regulation: A comparative structural equation modeling analysis," In Application of structural equation modeling in educational research and practice, pp. 115-133, 2013.

[15] Maison, Kurniawan, D. A., and Solihah, L. R., "Description of the Attitudes of Public Senior High School Students in Physics Subjects (in Bahasa)," Edusains, vol. 10, no. 1, pp. 160-167, 2018. 
[16] Tanti, Maison, A. Mukminin, A. Habibi, and Syamsurizal, "Exploring the Relationship between Preservice Science Teachers' Beliefs and Self-Regulated Strategies of Studying Physics: A Structural Equation Model," Journal of Turkish Science Education, vol. 15, no. 4, pp. 79-92, 2018.

[17] M. Baeten, F. Dochy, and K. Struyven, "The effects of different learning environments on students' motivation for learning and their achievement," British Journal of Educational Psychology, vol. 83, no. 3, pp. 484-501, 2013.

[18] F. Putra, I. Nur Kholifah, B. Subali, and A. Rusilowati, "5E-Learning Cycle Strategy: Increasing Conceptual Understanding and Learning Motivation," Jurnal Ilmiah Pendidikan Fisika Al-Biruni, vol. 7, no. 2, pp. 171, 2018.

[19] T. Rahayu, et al., "The Application of STAD-Cooperative Learning in Developing Integrated Science on Students Worksheet," Jurnal Ilmiah Pendidikan Fisika Al-Biruni, vol. 6, no. 2, pp. 247-254, 2017.

[20] Maison, et al., "Learning Environment, Students' Beliefs, And Self-Regulation In Learning Physics: Structural Equation Modeling," Journal of Baltic Science Education, vol. 18, no. 3, pp. 389-403, 2019.

[21] K. Vohs and A. Fishbach, "Self-Regulation," Wiley International Encyclopedia of Marketing (eds J. Sheth and N. Malhotra), 2010. [Online]. Available: https://onlinelibrary.wiley.com/doi/abs/10.1002/9781444316568.wiem03052

[22] B. J. Zimmerman, "Self-regulated learning and academic achievement: An overview," Educational psychologist, vol. 25, no. 1, pp. 3-17, 1990.

[23] F. T. Montalvo and M. C. G. Torres, "El aprendizaje autorregulado: presente y futuro de la investigación," Electronic journal of research in educational psychology, vol. 2, no. 1, pp. 1-33, 2004.

[24] M. F. Cheng, Taiwanese Young Children's Play in Ece Settings: A Study of Teacher and Child Behaviors Affecting the Development of Self-regulation. LAP LAMBERT Academic Publishing, 2011.

[25] D. M. Martens, Research And Evaluation In Education And Psychology Integrating Diversity With Quantitative, Qualitative, And Mixed Methods. Singapore: SAGE Publications Asia-Pacific, 2010.

[26] J. W. Creswell, Research Design Qualitative, Quantitative, And Mixed Method Aproach. Singapore: SAGE Publications Asia-Pacific, 2012.

[27] F. N. Kerlinger, Foundations of behavioral research. Yogyakarta: Gadjah Mada, 2014.

[28] L. Cohen, L. Manion, and K. Morrison, Research Methods In Education. Routledge, 2007.

[29] M. B. Miles and A. M. Huberman, Qualitative data analysis (2nd ed.). Thousand Oaks, CA: Sage, 1994.

[30] J. G. Borkowski, "Metacognitive theory: A framework for teaching literacy, writing, and math skills," Journal of learning disabilities, vol. 25, no. 4, pp. 253-257, 1992.

[31] A. Efklides and A. Tsiora, "Metacognitive experiences, self-concept, and self-regulation," Psychologia, vol. 45, no. 4, pp. 222-236, 2002

[32] D. L. Dinsmore, P. A. Alexander, and S. M. Loughlin, "Focusing the conceptual lens on metacognition, selfregulation, and self-regulated learning," Educational Psychology Review, vol. 20, no. 4, pp. 391-409, 2008.

[33] J. P, Scribner, "The Problems of Practice: Bricolage as a Metaphor for Teachers' Work and Learning," The Albertha Journal of Educational Research, vol. 51, no. 4, pp. 295-310, 2015.

[34] J. C, Richards, "Creativity in language teaching," Iranian Journal of Language Teaching Research, vol. 1, no. 3, pp. 19-43, 2013.

[35] M. M. Shahrebakbaki, "Relationships between Language Teachers' Time-management Skills, Creativity, and Burnout: A Mediation Analysis," Alberta Journal of Education Research, vol. 61, no. 1, pp. 20-39, 2015.

[36] S. Kingir, Y. Tas, G. Gok, and S. S. Vural, "Relationships among constructivist learning environment perceptions, motivational beliefs, self-regulation and science achievement," Research in Science \& Technological Education, vol. 31, no. 3, pp. 205-226, 2013.

[37] S. Velayutham and J. M. Aldridge, "Influence of Psychosocial Classroom Environment on students' Motivation and Self-Regulation in Science Learning: A Structural Equation Modeling Approach," Research in Science Education, vol. 43, no. 3, pp. 507-527, 2013.

[38] S. Hidi and J. M, Harackiewicz, "Motivating the academically unmotivated: A critical issue for the 21st century," Review of Educational Research, vol. 70, no. 2, pp. 151-179, 2000.

[39] M. Liu, D. Williams, and S. Pedersen, "Alien Rescue: A problem-based hypermedia learning environment for middle school science," Journal of Educational Technology Systems, vol. 30, no. 3, pp. 255-270, 2002.

[40] Maison., Astalini., D. A, Kurniawan., R. Perdana., and L. Anggraini, "The Phenomenon of Physicology Senior High School Education: Relationship of Students' Attitudes towards Physics, Learning Style, Motivation," Universal Journal of Educational Research, vol. 7, no. 10, pp. 2199-2207, 2019.

[41] S. Sungur, C. Tekkaya, and O. Geban, "Improving achievement through problem-based learning," Journal of Biological Education, vol. 40, no. 4, pp. 155-160, 2006.

[42] M. van Den Hurk, "The relation between self-regulated strategies and individual study time, prepared participation and achievement in a problem-based curriculum," Active Learning in Higher Education, vol. 7, no. 2, pp. 155-169, 2006.

[43] S. Sungur and C. Tekkaya, "Effects of problem-based learning and traditional instruction on self-regulated learning," The journal of educational research, vol. 99, no. 5, pp. 307-320, 2006.

[44] C. A. Wolters, "Understanding procrastination from a self-regulated learning perspective," Journal of educational psychology, vol. 95, no. 1, p. 179, 2003.

[45] D. H. Schunk and C. A. Mullen, "Toward a conceptual model of mentoring research: Integration with selfregulated learning," Educational Psychology Review, vol. 25, no. 3, pp. 361-389, 2013.

[46] B. J. Zimmerman, "Investigating self-regulation and motivation: Historical background, methodological developments, and future prospects," American educational research journal, vol. 45, no. 1, pp. 166-183, 2008. 
[47] K. D. Vohs and R. J. Faber, "Spent resources: self-regulatory resource availability affects impulse buying," Journal of Consumer Research, vol. 33, no. 1, pp. 537-547, 2007.

[48] A. Fishbach. and Y. Trope, "Implicit and explicit mechanisms of counteractive self-control," in J. Shah and W. Gardner Eds., Handbook of Motivation Science, pp. 281-294, 2007.

[49] H. K. Ning and K. Downing, "Influence of student learning experience on academic performance: the mediator and moderator effects of self-regulation and motivation," British Educational Research Journal, vol. 38, no. 2, pp. 219-237, 2012.

[50] D. Stipek, Motivation to learn: From theory to practice. Needham Heights. MA: Allyn \& Bacon, 1993

[51] S. L, Knight and H. C, Waxman, "Investigating the effects of the classroom learning environment on students' motivation in social studies," Journal of Social Studies Research, vol. 14, no. 2, pp. 1-12, 1990.

[52] M. Liu, "The Effect of a Hypermedia Learning Environment on Middle School Students' Motivation, Attitude, and Science Knowledge," Computers in the Schools, vol. 22, no. 3-4, pp. 159-171, 2005.

[53] H. C, Waxman and S. Y. L, Huang, "Motivation and Learning Environment Differences in Inner-City Middle School Students," The Journal of Educational Research, vol. 90, no. 2, pp. 93-102, 1996.

[54] Astalini, D. A. Kurniawan., U. Sulistiyo, U., R. Perdana., S. Susbiyanto, "E-Assessment Motivation in Physics Subjects for Senior High School,” International Journal of Online and Biomedical Engineering (iJOE), vol. 15, no. 9, pp. 4-15, 2019.

[55] Maison, et al., "Learning in Nature Science: Social Implication, Normality of Scientist., Attitudes Towards Investigation of Natural Science, and Interest Adds To Science Learning Time," International Journal of Scientific \& Technology Research, vol. 8, no. 12, pp. 1478-1484, 2019.

[56] M. Alfassi, "Promoting the will and skill of students at academic risk: an evaluation of an instructional design geared to foster achievement, self-efficacy and motivation," Journal of Instructional Psychology, vol. 30, no. 1, pp. 28-40, 2003.

[57] K. Downing, R. Ho, K. Shin, L. Vrijmoed, and E. Wong, "Metacognitive development and moving away," Educational Studies, vol. 33, no. 1, pp. 1-13, 2007.

[58] O. Talib, W. S, Luan., S. C Azhar. and N. Abdullah, "Uncovering Malaysian students' motivation to learning science," European Journal of Social Sciences, vol. 8, no. 2, pp. 266-276, 2009. 